Article

\title{
Normal Peace: A New Strategic Narrative of Intervention
}

\author{
Nicolas Lemay-Hébert ${ }^{1, *}$ and Gëzim Visoka ${ }^{2}$ \\ ${ }^{1}$ International Development Department, University of Birmingham, Birmingham, B15 2TT, UK; \\ E-Mail: n.lemayhebert@bham.ac.uk \\ 2 Institute for International Conflict Resolution and Reconstruction, School of Law and Government, Dublin City University, \\ Dublin, D09 Y074, Ireland; E-Mail: gezim.visoka@dcu.ie \\ * Corresponding author
}

Submitted: 31 March 2017 | Accepted: 12 July 2017 | Published: 29 September 2017

\begin{abstract}
International actors have used multiple discursive frameworks for justifying interventions, from human security to the responsibility to protect, and, most recently, resilience-building. We argue that the language of normalization, hidden behind these narratives of interventions, has also contributed to structure the intervention landscape, albeit in less obvious and overt ways than other competing narratives of intervention. This article disentangles the different practices of normalization in order to highlight their ramifications. It introduces the concept of normal peace-a new conceptual reference to understand interventions undertaken by the international community to impose, restore or accept normalcy in turbulent societies. The article argues that the optimization of interventions entails selective responses to govern risk and adapt to the transitional international order. The art of what is politically possible underlines the choice of optimal intervention, be that to impose an external order of normalcy, restore the previous order of normalcy, or accept the existing order of normalcy.
\end{abstract}

\section{Keywords}

international intervention; normal peace; normalization; peacebuilding; resilience

\section{Issue}

This article is part of the issue "Narratives of Global Order", edited by Matthew Levinger (George Washington University, USA) and Laura Roselle (Elon University, USA).

(C) 2017 by the authors; licensee Cogitatio (Lisbon, Portugal). This article is licensed under a Creative Commons Attribution 4.0 International License (CC BY).

\section{Introduction}

The narratives of normalcy and normalization have been present for some time in the social practices of peacebuilding and in broader International Relations (IR) debates, but there has been a lack of explicit effort to theorize their meaning(s) in practice. The notion of 'normalization' in the IR discipline has more often than not been used interchangeably with the notion of 'peace', and the re-establishment of diplomatic relations (Bull, 1977). In peace and conflict studies, normalcy is invoked interchangeably as a normative goal of peacebuilding, as an intermediary measurement of success towards sustainable peace, or as a processual mechanism facilitating other post-conflict processes (e.g. 'reconcilia- tion' or 'good governance'). For instance, the United Nations (UN) has used normalcy in parallel to the notions of peace, stability, and reconstruction (UN General Assembly and Security Council, 2005, p. 19). Certain UN policy documents explicitly treat normalcy as a passage to peace consolidation and recovery (UN Peacebuilding Support Office, 2012). In other instances, normalcy is invoked as a politics of care towards local subjects and an aspirational mechanism for generating local acceptance and validity for the external rulers (UN, 2008). Similarly, the European Union (EU) has started to invoke 'normalization-building' as a rationale for describing its conflict-resolution and crisis-management operations abroad. Javier Solana, the EU's first High Representative for Foreign and Security Policy, argued that 'crisis 
management missions have been at the heart of the EU's stabilisation and normalisation efforts in the Balkans' (European Union Institute for Security Studies, 2013, p. 3). How should we make sense of these very diverse narratives of normalcy? This paper argues that these different praxeological invocations of normalcy and normalization have not been given the level of interest that they deserve in the field of IR, and peace and conflict studies more precisely, for two main reasons. First, because these social practices have been subsumed within other general interpretative categories (see, for instance, the vibrant literature on 'liberal peacebuilding', but also the Responsibility to Protect, the human security or resilience literatures), which have obscured more than revealed normalization practices. Second, when normalcy and normalization narratives and practices have been specifically analysed, specific form of interventions have generally been treated separately and in disconnection with the knowledge base in IR and in peace and conflict studies that gives meaning to these normalcy interventions. In this article, we will mobilize-in more an illustrative than a systematic fashion-three specific literatures in the field of peace and conflict studies, with the aim of linking these literatures with specific sets of normalization practices: fragile states and liberal peacebuilding (imposing normalcy), resilience (restoring normalcy) and indigeneity and authenticity (accepted normalcy).

We argue in this article that normalization can be understood as a reformulation of existing governmentality practices, while at the same time representing a new strategic narrative that seeks to legitimate existing interventionary practices, and when necessary to adjust to the fluid international order. We assemble the broad variety of discourses and practices on normalization in peacebuilding, and make sense of these interventionary practices by presenting them in a continuum of practices of domination and of the management of individuals and societies: from the imposition to the restoration and acceptance of normalcy. The fluidity and optimization of discourses and practices of normalcy articulated through an assemblage of interventionary measures (Visoka, 2017b) represent a will to govern which is not necessary attached to liberal normative frameworks, but constantly changes the referent objects of intervention.

The first mode of normalization, imposing normalcy, implies external intervention in a particular society considered as being 'abnormal' due to the experience of violent conflict or being generally considered 'fragile' and in need of intervention. These societies are conceptualized as in dire need of normalization through the imposition of external blueprints of normalcy, in the form of norms, rules, standards, practices in distinct areas of governance, institutions, economy, social relations, and culture. The second mode of normalization, restoring normalcy, encompasses practices that seek to restore a society to its previous condition, a condition deemed normal and acceptable for international and local actors after experiencing a particular difficulty that required exter- nal assistance. The third and final form of normalization, accepting normalcy, implies the acceptance of a particular local version of normalcy by external actors, as either a strategic withdrawal of governance responsibilities or ontological permutation of difference. We refer to these three sets of social practices taken together as normal peace, which lies at the intersection between the governmentality of other and 'the self', enabling specific forms of intervention to regulate or deal altogether with the societies deemed 'abnormal' or 'dysfunctional'. This discussion echoes Roberto Esposito's discussion of the immunological pursuit of self-preservation against the other as a progressive 'interiorization of exteriority'. What remains constant for Esposito is 'the place where the threat is located, always on the border between the inside and the outside, between the self and the other, the individual and the common' (Esposito, 2008, p. 2). It is the recognition that the other is not simply external to me, which is to say, other to me (Donà, 2006, p. 57). It 'takes the outside inside' (Donà, 2006, pp. 57-58) and forms a dialectic of the excluding inclusion or inclusive exclusion.

Three modes of normalization elaborated in great length in this article constitute the dominant narrative of normal peace, which encompasses a broad range of fluid narratives and strategic frameworks for making sense of intervention and non-interventions in the turbulent societies. In this context, normal peace can be defined as a set of governmentality practices aimed at disciplining and regulating societies deemed 'abnormal' or 'dysfunctional' through wide-ranging forms of interventions. In turn, normalization practices-imposing, restoring, and accepting normalcy-are 'made possible' by specific discourses (Foucault, 1988, p. 19). In our case, three specific discourses, or more appropriately knowledge, enable normal peace practices: the failed or fragile states discourse and its counterpart, the liberal peacebuilding discourse, are associated with imposing peace; the discourse on resilience is associated with restoring normalcy; and the discourse on indigeneity is associated with accepted normalcy. These discourses, associated with the underlying sets of practices, in turn, inherently shape the governmentality practices behind normal peace. The governmentality of normal peace lies, then, at the intersection between the technologies of domination of others and those of the self, and the interplay between the two enables different actors to create the subjects of interventions as well as to legitimize specific forms of international peacebuilding interventions.

Accordingly, unveiling various mutations of new strategic narratives governing international interventions and their unprincipled and political interests has far-reaching consequences for the normative credibility of Western democracies and global institutions. This paper is organized as follows. First, we explore the concepts of normalcy and normalization by linking them with the work of Foucault. We then explore in more detail the technologies of normalization in the specific context of peacebuilding interventions by looking alternatively at 
imposed, restored, and accepted normalcy. The paper concludes with a problematization of the contemporary politics of normalization by looking at the ramifications of the normal peace agenda.

\section{On Being and Becoming Normal}

Narratives are important epistemological categories for making sense of social world. In essence, narratives represent condensed interpretation of meanings, norms, values, events, social facts, and experiences (see: Elliott, 2005; Herman \& Vervaeck, 2001). They can take the shape of policy discourses, stories, and textual and performative articulations. Conceptual narratives of normalcy and normalization have been variously defined in different disciplines, making the notions essentially contested and contingent on semantic interpretations. For a start, Sigmund Freud is often associated with the conceptualization of normalcy-through his psychoanalytical perspective-while Michel Foucault has been at the forefront of developing a critical account of the historicity of normalization practices; Freud engaged in exploring the inner constraints of normalization (Ipperciel, 1998), whereas Foucault focused on the external forces, powers, and technologies of normalization. While Freud's perspective is to a certain extent relevant for our study, we are more interested in exploring the external dimensions of normalization through the prism of different technologies of knowledge and practice. Foucault approached normalcy and normalization from the perspective of the biopolitics of power, governmentality, and disciplinary technologies. He has been highly influential in developing critical accounts in peace and security studies, which led to the development of the field of international political sociology (see indicatively: Bonditti, Bigo, \& Gros, 2017). While Foucault's work on bio-politics, resistance, and governmentality has been extensively applied to the subfield of peace and conflict studies, his work on normalization has been examined more often than not indirectly as a by-product of other related notions. Foucault held that the idea of normalization is to impose precise norms without having to resort to punishment, thus representing the most 'advanced' form of interventionism in society. Essentially, the production of norms is the production of power, which requires people to change their practices to ensure conformity with collective social norms (Taylor, 2009 , p. 52). For Foucault (2003, p. 50), the norm is an 'element on the basis of which a certain exercise of power is founded and legitimized'. Thus, normalization is the hidden governance of social relations in the wake of modernity and the perceived necessity for governing all aspects of society. The purpose of disciplinary technology is to ensure the compliance of society with certain norms, where the punishment is hidden in the institutional mechanisms of governance. Hence, normalization is:

a system of finely gradated and measurable intervals in which individuals can be distributed around a norm - a norm which both organizes and is the result of this controlled distribution. A system of normalization is opposed to a system of law or a system of personal power. (Robinow, 1984, p. 20)

As Foucault (2003, p. 50) holds, 'the norm's function is not to exclude and reject. Rather, it is always linked to a positive technique of intervention and transformation, to a sort of normative project'.

For Foucault, the normal is determined through its opposite-the abnormal-whereby the differentiation of these two constitutes their distinctions. The practice of this distinction between normal and abnormal enables the delineation of identity and the production of power. Abnormality has historically evolved through the practice of 'expert medico-legal opinion', which holds the power to determine the field of normal from the abnormal. Through the discussion of abnormality, Foucault (2003, p. 61) tried to explain the technology of human abnormality', which for him 'appears precisely when a regular network of knowledge and power has been established that brings the three figures together or, at any rate, invests them with the same system of regularities'. This conception of abnormality then, in turn, allows or justifies psychiatric and administrative interventions. This signifies that the technology of normalization requires the creation and classification of anomalies and deviations, as well as the isolation or reformation of these abnormal individuals through coercive, corrective, or therapeutic interventions. Foucault also argues that the imposition of a particular regime of normalcy and homogeneity goes hand in hand with the production and systematization of knowledge, which supports the normalization of social affairs. This hegemony of normalcy is the main trigger of resistance, which seeks to normalize another set of phenomena, which are perceived as being abnormal (Bigo, 2008, p. 99). Hence, for Foucault, questioning norms and unmasking their effects on power opens up many possibilities for preserving and expanding freedom (Taylor, 2009, p. 46). Normalization can hardly be considered to contribute to the politics of empowerment simply because its very logic is situated on the binary between the forces that possess the knowledge and authority to normalize others and the devalued, discredited ones who are deviant and 'in need of treatment'. Every practice of normalization results in a process of marginalization and exclusion of other practices deemed abnormal.

\section{How Things Become (Ab)Normal: Normalization in Practice}

During the Cold War era, interventions to discipline and regulate societies were mostly reframed and understood, by academics and policy-makers alike, through the lens of ideological affiliation and a bipolar world order. After the age of bipolar rivalry, post-Cold War interventions have been framed, rather, within the strategic nar- 
ratives of humanitarian intervention, human security and the responsibility to protect, liberal peacebuilding, and resilience. These multiple narratives serve to cast light from a specific angle, obscuring other phenomena in the process. While specific references to normalcy and normalization have been and are still frequent in interventionary discourses, they have been subsumed within wider analytical categories and have hence lost all their specific and autonomous meanings (see Miskimmon, O'Loughlin, \& Roselle, 2017). It is therefore central to understanding practices of normalization in the context of intervention and peacebuilding to explore specific techniques that the international community-defined here as formal and informal assemblages of state and non-state actors around the UN, regional organizations or more ad hoc coalitions-invoke to deal with 'turbulent societies' that represent a threat to or disturbance of what is perceived as a normal state of affairs in the society of states. Understanding the politics of normalization requires exploring the technologies of selectivity, namely when to consider something normal and when to brand it as 'abnormal', when to intervene to impose and restore normalcy, and when to conveniently accept the heterogeneity of normalcy and co-exist with other 'abnormalities'.

\subsection{Imposed Normalcy: Creating Liberal Subjects}

Externally imposed normalcy has been particularly salient in post-conflict societies affected by civil war and internal violent conflict, through stabilization, peacebuilding, and statebuilding interventions (Lemay-Hébert, 2009; Visoka, 2016a). Imposed normalcy practices are made possible through a specific reading and mapping of the world as being composed of 'strong', 'efficient', and hence 'sovereign' states at one end of the spectrum, and weak, failed, and collapsed states in need of transformation and intervention at the other. Framing conflict-affected societies as 'abnormal', 'violent', 'illiberal', or 'fragile' justifies external intervention to impose normalcy. These signifiers, each in their own way, act as prescriptive terms, 'employed in connection with the contemplation and execution of international involvement' (Jackson, 2004, p. 22). Hence, imposed normalcy takes all its meanings through an approach of abnormalization of specific societies seen as unable to manage their own affairs or 'perform functions necessary to meet citizens' basic needs and expectations' (Organisation for Economic Co-operation and Development [OECD], 2008; on a critical take on OECD's interpretation of fragile states, see Lemay-Hébert \& Mathieu, 2014). The process of abnormalization may involve an assemblage of different techniques, such as discursive statements, framing of events, and audio-visual evidence, which help constitute over time a particular image of abnormality. This process of abnormalization of local societies might disregard local knowledge and practices which can be considered normal in Western societies. However, without such discursive abnormalization intervention might be deemed as unnecessary, which is not what external actors often desire.

In this context, state 'performance' becomes the yardstick of normalcy, whereby liberal democracies are instituted as models of governance (Lemay-Hébert, 2013). Normalcy is defined as a fairly specific set of functions every state is supposed to perform (seen through a technocratic or institutionalist lens, i.e. what requirements the state should meet) and as a set of ideals to which actors and institutions have to conform (through a normative lens, i.e. how the state should meet its requirements). This enables the ranking of states according to their performance, which leads to the identification of the 'core of monstrosity behind little abnormalities' (Foucault, 2003, p. 56). The discourse on fragile and failed states is directly linked with practices of normalization, thereby legitimizing the imposition of a particular normalcy in countries considered pathologically ill or unable (or unwilling) to govern themselves. If we follow existing statistics and rankings of state performance, there are currently 34 fragile states, and over 60 per cent of the world's population live in undemocratic societies. This naturally opens up perspectives of intervention in these 'dysfunctional' societies. As Caroline Hughes and Vanessa Pupavac $(2005$, p. 873) argue, this global discourse 'fixes culpability for war on the societies in question, rendering the domestic populations dysfunctional while casting international rescue interventions as functional'. In this context, one could argue that the international order fundamentally rests on 'techniques of transformation of abnormal elements into responsible and well-functioning members of a community' (Zanotti, 2006, p. 152). Hence, this is the dual nature of the discourse-defining certain 'Western' societies as normal while considering those that do not conform to the standard as 'abnormal' - that effectively opens up the possibility of imposing normalization practices.

Knowledge production about conflict societies is at the heart of the technology of international normalization. Since the end of the Cold War, the discourse of normalization has been invoked by scholars as a problemsolving approach to violent conflicts. In her early writing, Mary Kaldor (1996, p. 510) proposed creating zones of 'normality' to protect civilians from violent conflict, thus creating conditions for normalization through robust peacekeeping and international administration. Bridging peacekeeping and peacebuilding, Kaldor (1996) held that 'after cease-fire agreements, the tasks of peace-keeping have to be extended beyond the separation of forces to civil security in order to establish peace-time conditions and assist 'normalization', including freedom of movement, the return of refugees, and the capture of war criminals'. She equates peacebuilding with normalization as a stage that precedes a settlement. Others equate normalcy with reconstruction. Lorraine Elliott (2003, p. 272) argues that 'social reconstruction or normalisation, and the rebuilding of a just and equitable civil society, are es- 
sential components of long-term peacebuilding'. Elliott considers as 'social normalization' working with vulnerable groups in the society through therapeutic interventions, material support, and service provision. Moving from normalcy as a processual stage to the desired end goal, Richard Caplan (2005, p. 198) defines 'normality' as 'a stable peace and the establishment of effective mechanisms of domestic democratic governance'. Other entities consider normalization as the final stage of postconflict recovery, when extraordinary measures are removed, self-sustainability of peace is established, and the internal and external relations are conducted according to generally accepted norms of behaviour' (Center for Strategic and International Studies, 2002, p. 2).

Imposing normalcy on 'abnormal' states then becomes a normal-even irrefutable-practice, which 'naturally' flows from the diagnostic posed by scholars and the various indices of state failure created to support these practices (Grimm, Lemay-Hébert, \& Nay, 2014). The list of countries where normalcy was imposed by outside forces-either through peacebuilding missions or other forms of intervention-is long and covers all regions of the world. Many examples of UN peacebuilding missions comprise normative agendas that consist of external blueprints for democratization, good governance, the rule of law, neoliberal economics, and liberal civil society, which are considered as prerequisites to enforcing 'normal social relations' after violent conflict (Väyrynen, 2010, p. 140). Most evidently, many peacebuilding interventions aim to build 'normal societies' that vaguely mimic Western democratic societies. Such regimes of norms, practices, and values are imposed on 'abnormal post-conflict societies' to ensure their normalization with a new political and societal order to maintain stability, peace, and development and prevent the recurrence and spillover of violence.

External normalization practices entail a degree of alienation, whereby changing existing cultural and collective referent systems is considered a new normalcy. Local social norms and order are deemed incompatible with the possibility of peace, which in turn necessitates external engineering of local norms of how to regulate social and political relations (Lemay-Hébert \& Kappler, 2016). Interventions seek to impose new social conventions through 'capacity-building' programmes, knowledge transfer, and learning by undertaking mentorships. The technology of normalization is legitimized through the use of 'blueprints' and 'best practice' regimes, which seek to increase local acceptance of the intervention and remove any competing local know-how registers. Local culture and social order in conflict-affected societies are classified as failed, illiberal, and traditional, and thus cannot be included in the 'solution' (Visoka, 2017a). The very fact that those societies have failed to maintain peace and have become a source of regional instability means they are seen as having lost their civility. The ontology of imposed normalcy is rooted in the logic that institutions and norms such as democracy, human rights, the rule of law, and the market economy are universal by nature and thus can be adjusted to be applicable to postconflict societies through technical intervention.

At the heart of the normalization of post-conflict societies has been a process of normative production, which entails imposing new norms to govern peace, stability, and development in these war-shattered societies. Strong emphasis on institution-building aims to generate predictable social and political behaviour and establish a social contract with strong political obligations for citizens (Visoka \& Richmond, 2017). New regulatory regimes are imposed to govern political life in such a way as to ensure ethnic accommodation and reduce local resistance to and accept the authority of international interveners. For example, the international community implanted new, modern legislation in Kosovo that aimed both to bind the country to the highest democratic standards and to facilitate its eventual integration into the EU (Guéhenno, 2015). Normalization requires strong enforcement capabilities. In certain places, such as Timor-Leste, the international community has deployed armed peacekeepers and international police to enforce post-conflict stabilization and facilitate the implementation of peacebuilding and statebuilding agendas (Harris \& Goldsmith, 2011). Hence, normalization can be imposed through military rule as well as soft interventions through international neo-trusteeships, ad hoc technical assistance, and shuttle diplomacy.

\subsection{Restored Normalcy: Building Resilient Subjects}

In another set of discourses and practices, normalcy and normalization have been alternatively justified as interventions that aim to facilitate the return to 'conditions before the intervention' (Kratochwil, 2010, p. 198), a situation deemed normal and acceptable for international and local actors. Interventions for restoring normalcy are seen as successful even if they only entail a return to dismal pre-conflict levels, which are primarily concerned with the creation of the effect of 'semblance of normalcy' (Tamer-Chammas, 2012, p. 218). In this cluster of social practices, normalcy is understood both as a willingness for conflict-affected societies to return to antebellum social, political and economic conditions, while at the same time being linked to local and international perceptions of what constitutes 'stability' in this context. Hence, most restored normalcy practices do not lead to a return to a mythical 'previous condition', or 'pre-event norms,' but instead create new features of normalcy-a mirror image of the status quo ante that does not, however, exactly match the original image of normalcy. In these contradictory invocations, the narrative of resilience represents an attempt to convert extraordinary and emergency conditions into normal conditions of co-existence with violent abnormalities.

The discourse of restoring normalcy as a return to the status quo ante can be found in numerous interventions, which include a wide variety of actors. In this context, lo- 
cal businesses can be seen as having a large role in restoring 'some form of normalcy' in a post-conflict setting while being instrumental in promoting 'pockets of normalcy' during conflict (Sweetman, 2009, p. 57). The same could be said of traditional, non-state leaders who have been identified as crucial actors in 'restoring some semblance of normalcy and security' in Darfur (Tubiana, Tanner, \& Abdul-Jalil, 2012, p. 102), in Somalia (Jeng, 2012, p. 272) or in Sierra Leone (Martin, 2016). The discourse of restoring normalcy has also found traction in the disaster relief literature, where it has come to be associated with recovery efforts, defined as the protracted process of recuperating pre-event norms. This is a discourse that has been used in numerous post-disaster situations, such as the Philippines after Typhoon Haiyan (Tisdall, 2013).

In this context, restoring normalcy can be traced to the burgeoning discourses and practices of resiliencebuilding in conflict- and disaster-affected societies. The resilience-building discourse is replete with 'building back better' semantics. For instance, the United Nations Development Programme (2010, p. 19) presents its recovery efforts as focusing largely on 'restoring normalcy following a crisis, transitioning effectively from crisis to development, and using recovery work as an opportunity to build back better'. Similarly, resilience is about adaptability and recovery, and as such resilience seeks to normalize instability through a succession of various forms of intervention (Anderson, 2015, p. 62). For instance, the $\operatorname{OECD}(2011$, p. 15) defines social resilience as 'the capacity of a community (or organisation) to adapt under adverse conditions and restore a sense of normalcy from an external shock'. In this context, resilience entails coming to terms with a permanent state of affairs made of contingency, adaptability, vulnerability, and instability. In their critical account of resilience, Brad Evans and Julian Reid (2014, p. 3) argue that instability and insecurity are the new normal as we become increasingly attuned to living in complex and dynamic systems which offer no prospect of control'. The resilience-building discourse is closely linked to the failure to impose normalcy, as discussed earlier. Hence, resilience signifies the recognition of external limits to (re)build political structures and to drastically transform 'abnormal' post-conflict societies. Such realization permits changing the focus of interventions from transformation to self-management and confinement of risks.

Although emergencies are defined as 'urgent situations created by an abnormal event' (OECD, 2006), they are no longer exceptional and extraordinary events. The amplification and repetition of vulnerabilities has brought them to the point of normalization. Emergencies have increasingly become normal events, which remain for 'the subject to learn to take care of their own endangered destinies' (Evans \& Reid, 2014, p. 89). The UN Office for the Coordination of Humanitarian Affairs $(2015$, p. 3) argues that 'protracted is the new normal', referring to the longevity of humanitarian crises and highlighting the international reluctance to end protracted crises. After the realization that stability is a myth, resilience "becomes a normalized standard for mapping out (ab)normal behaviours such that the very terms of success are loaded with moral claims to a specific maturity' (Evans \& Reid, 2014, p. 103). Craig Calhoun (2008, p. 67) suggests that 'today we see not one large emergency dismissed as an exception, but innumerable smaller ones still treated as exceptions to an imaginary norm but repeated so frequently as to be normalized'. The normalization of emergencies makes resilience a coping mechanism to deal with anticipated and permanent crises. This instability is not viewed as necessarily abnormal in this framework, and conflicts and disasters are seen not 'as deviations of the normal state of affairs' but as inherently constitutive of the reality many Third World countries face on the everyday level. Interventions are not confined to exceptional situations but acknowledge the continuities and discontinuities between crisis and normalcy (Duijsens \& Faling, 2014, p. 172). This approach moves towards a 'vulnerability framework' where normal daily life becomes difficult to distinguish from disaster (Wisner, Blaikie, Cannon, \& Davis, 2003, p. 10). However, this shift not only ignores the root causes of turbulent events, but also disregards the multiplicity of consequences that are now deemed as normal and expected.

Paradoxically, the technology of restoring normalcy entails both the optimization and withdrawal of responsibility for previous failures to impose and maintain normalcy, as well as new tactical interventionism which seeks to impose normalcy through building resiliency and self-sufficiency (Chandler, 2014). Thus, the very act of striving to build autonomous societies locks local societies into new forms of dependence on external resources and expertise, and unequal power relations. In other words, international efforts to restore normalcy represent a renewed rationale to govern risks and vulnerabilities at their source and suspend any modernist fallacy about progress or stability. The narrative of resiliency is gradually becoming a withdrawal symptom from the liberal aspirational politics of global progress and positive transformation of human condition while preserving same old fluid interventionary practices without the burden of local acceptance and global legitimacy.

\subsection{Accepted Normalcy: Coping with Difference}

A third set of narratives and practices revolves around accepting normalcy, where international actors seek to manage risks through recognition of the plurality of ways of life. Like the two other categories of normalization practices, recognising alterity and coping with difference is unfolding both as a knowledge production process and as a set of practices. In the context of normal peace, accepting the world as it is takes on two major meanings. First, accepting normalcy can take the shape of an exit strategy for interveners after failed attempts to impose or restore normalcy and, at the same time, works as a discursive tactic to avoid the responsibility of any undesired 
results (see Visoka \& Doyle, 2014). Second, accepting normalcy is also used as a discourse to justify and legitimize non-intervention towards societies which could be labelled as 'abnormals' from a universalist perspectivefor instance, societies experiencing internal troubles and not following normative regimes of human rights. The discourse on heterogeneity and indigeneity informed by cultural relativism is often advocated by critical scholars as a pathway for finding alternative paradigms to building sustainable peace after violent conflicts. For various reasons, international actors come to accept this 'abnormality' as a new form of normalcy, and implicitly or explicitly recognize the limits of external imposition or restoration of normalcy in the process of reshaping these societies. Combined, these two types of knowledge enable new forms of practices of accepted normalcy.

Accepting normalcy of conflict-affected societies, fragile states, and disaster-affected places has become synonymous with 'the art of what is politically possible' (Donais, 2012, p. 152). It represents coming to terms with the practical limits of international interventions, which does not represent the end of interventions but rather signifies the birth of new modes of governance through failure and crisis. In the context of recalcitrant local actors and resilient social structures, peacebuilding actors can soon become disillusioned with what it is actually possible to achieve in particular 'theatres of operations'. From the deeply embedded warlord structure in Afghanistan to clans in Somalia and the mafia in the Balkans, international interventions have 'feet of clay' (Mac Ginty, 2011, p. 2), and international officials more often than not are forced to recognize the limit of their transformative agenda in peacebuilding contexts.

Transcending the categories of 'successful missions' (such as ONUSAL in El Salvador) or 'missions which failed to complete their mandate' (such as UNAMIR in Rwanda)-categories usually linked to mainstream conceptualization of exit strategies (Caplan, 2012; UN, 2001) - accepted normalcy can either take the shape of a hasty exit from the country, thus recognizing the impossibility of carrying out a specific mandate, or be associated with so-called successful missions, with focus shifting from social transformation to 'good enough peacebuilding' (Donais, 2012, p. 151). The UN Secretary-General's report 'No exit without strategy' exempts the UN from responsibility for its partial success or failure by considering that the role of the United Nations is merely to facilitate the process that seeks to dismantle the structures of violence and create the conditions conducive to durable peace and sustainable development' (UN, 2001, p. 2). However, accepted normalcy can also signify the ignorance of the international community in resolving a conflict and can serve as a neo-colonial effort to compartmentalize a particular conflict. Richard Caplan (2006, p. 254) argues that exit strategies should be pursued in proportion to the sustainability of peace, while acknowledging that exit 'can also be a political matter, the pace of which may be determined by domestic and international factors that have little to do with the preparedness of a territory'.

Accepting alterity has also taken prominence in the critical literature on peacebuilding, with voices calling for a rethink on external interventions and the acceptance of 'local' and 'indigenous' forms of peacebuilding. In this context, accepting normalcy involves recognition of the importance of local cultures, knowledge, traditions, and needs, while accepting local practices of conflict resolution and organization of political community, however unpalatable to international officials these practices may be. For instance, Oliver Richmond (2008, p. 116) considers external peace frameworks for governance enshrined in rational and technical problemsolving logics as 'normalising governance activities' that aim to transfer 'liberal epistemologies into conflict zones'. He further argues that 'local decision making processes should determine the basic political, economic, and social processes and norms to be institutionalized in context' (2011, p. 112), and maintains that peace 'emerges from local and indigenous agency, rather than being prompted externally' (2013, p. 384). For Roger Mac Ginty (2008, p. 139), 'traditional and indigenous approaches to peace-making and reconciliation can offer a corrective to the failings of the Western peace-making model', hence making peace the 'restoration of resonant normality to everyday life' (Kappler \& Richmond, 2011, p. 274). This critical alternative to top-down liberal governance leans more towards accepting local normalcy in its cultural, social, and everyday manifestations, while considering external support as necessary to enable local peace formation and emancipation from inequality and discrimination, and to promote autonomy from external political, economic, and socio-cultural tutorship. It has to be noted that this discourse has been criticized as retaining certain elements of the more mainstream liberal interventionist paradigm, especially in its understanding of the disputed 'local' (Hameiri \& Jones, 2017; Randazzo, 2017; Visoka, 2016b).

The discourse of accepted normalcy is also evident in the cooperative practices of the international community with regard to authoritarian regimes, such as Bahrain and Saudi Arabia, or societies with 'internal troubles', such as Israel. Despite the fact that these societies are engaged in widespread torture and human rights abuses, have breached international law, and have suppressed minorities, these authoritarian, turbulent places continue to enjoy extensive international acceptance. This accepted normalcy is often justified in terms of the war on terror and geopolitical stability, which provide a blanket reasoning and selectivity for non-intervention. For instance, the discourse of accepted normalcy was evident when the UK House of Commons Foreign Affairs Committee did not consider Bahrain's failed revolution a civil war, despite extensive use of violence by police against protesters; it concluded that 'life, on the whole, continues as normal' (House of Commons, 2013, p. 106). The powerful discourse on normalcy propagated 
by Israel and its allies has suppressed the scale of violence committed in Gaza, the West Bank and other occupied territories. However, these repressive practices are justified as acts of self-defence and protection of democratic society. By calling Israel a democracy, the exemption from intervention is institutionalized and thus abnormal practices are camouflaged, silently tolerated, and accepted by the international community. Although Saudi Arabia is widely criticized for harsh domestic policies and is considered a significant source of terrorist funding in the Middle East and beyond, the US and other Western democracies continue to consider it a major foreign-policy ally, and thus treat these domestic and global sources of insecurity as normal (see: Blanchard, 2015). These examples signify that the discourse of accepted normalcy inverts discourses of intervention to justify non-intervention, holding thus the exception to determine what constitutes a normal or abnormal affair in world politics. However, in the process, accepting the 'abnormal' other comes down to transforming the self, where conceptions of normality are at risk to be radically transformed. The exception risks becoming the rule when we 'take the outside inside', that is to say when there is a 'substantial assimilation of the other into my horizon' (Donà, 2006, pp. 57-58). Our own conceptions of normality end up dramatically transfigured through this complex interaction between the self and the other.

Finally, the discourse and practices on accepting multiple normalcies signifies the optimization of interventions in such a way that, when imposing or restoring normalcy is not possible, the 'abnormal' state of affairs is accepted and legitimized internationally. It is a paradigm of retreat from external, coercive regulation, in a context where policymakers are finding it increasingly difficult to formulate and impose a coherent political project for 'othered' societies (Finkenbusch, 2017). Thus, accepting normalcy not only blurs international norms, but challenges them and undermines the credibility of global governance. Nevertheless, accepting normalcy can signify the end of a particular regime or normalization, and simultaneously the birth of a new understanding of normalcy, which entails new disciplinary modes and transactions in international politics.

\section{Conclusion}

This article points to the existence of different discourses and practices of normalization which seek to 'make sense' of international interventions in turbulent societies. In contrast with approaches that emphasize the novelty of specific interventionary forms, this article has offered an alternative perspective, focusing on how narratives and practices of normalization include both elements of continuity and change-encompassing both the continuation of 'traditional' interventionary dynamics and the emergence of new post-interventionary dynamics. In casting the technology of normalization in 'turbulent societies', this article focused on a number of dis- tinctive sets of discursive practices, ranging from interventions in 'abnormal' societies that seek to reform and transform through the imposition of external blueprints of normalcy to interventions that seek to restore societies to their ante bellum state, as well as new emerging features of accepting normalcy, where local versions of 'peace' are accepted. Despite the efforts of many societies to construct alternative normalities, the quest for governmentality of different ways of life has found ways of intervening with ever-shifting rationales and justifications. The resulting 'order' emerging from these governmentality practices can take different shapes and forms depending on the specific context of interventions: it can be a liberal in nature through imposing peace practices-even if this strand of intervention has lost steam recently-but it can also be quite conservative in nature through restoring peace practices, or even isolationist or minimalist through accepting peace practices.

In this context, we believe that normal peace has the potential to become an umbrella notion to understand past, present and future multi-faceted interventions, ranging from peace-making to peacekeeping, stabilization missions, peacebuilding, and resilience-building. We see the progressive emergence of the discourse of normalization as gradually replacing other interventionary paradigms. In specific instances, especially in the context of the accepted normalcy and restored normalcy discourses, this change of paradigm indicates a postinterventionary shift, representing a reduction of expectations vis-à-vis conflict-affected societies as well as a realization of the limits of liberal interventionism, and serve as a tactical withdrawal from international responsibilities towards targeted societies. What was first perceived as 'abnormal' suddenly becomes normal and acceptable. Victims of conflict become either resilient subjects or actors of their own destiny, left to their own devices. It is in the context of all-encompassing attempts to govern risks that discourses of resilience, acceptance of difference, and permanence of crisis are becoming enabling frameworks which legitimize optimal normalization expressed in both more radical and fluid forms of intervention.

Through this cursory review of normalization narratives and practices, we suggest and hint at a shift in focus from peacebuilding to normalising turbulent societies, where peace is not seen only as a process either brought from outside (liberal interventionism or topdown governance) or constituted from inside (emancipatory or everyday forms of peacebuilding), but also as a mix of social practices-policies and discoursesproduced by and through knowledge production. The discursive knowledge on fragile states, illiberal social orders of conflict-affected societies, resilience, and permanence of crisis, as well as failure and acceptance of alterity, has a direct role in legitimizing particular forms of normalization. It is the intersection of both 'worlds' the policy and academic spheres - that enables the constitution of the meanings of normalcy and normalization 
practices identified in this article. This necessitates questioning the impact of knowledge production in normalizing and abnormalizing discourses and practices of peace. From liberal peacebuilding discourses and debates to the resilience literature and emancipatory peacebuilding literature, this article has drawn together different sets of discursive policies that shape the field of international normalization practices. It is therefore crucial to recognize that knowledge production about turbulent societies has a direct impact in shaping discursive and practical aspects of intervention. What we see emerging is a need to further theorize normalcy and normalization practices across different disciplines to make sense of its praxeological and discursive invocation in contemporary global affairs. Therefore, what this study points out is that dominant normative frameworks-such as governance, stability, peace, justice, development-guiding international interventions are inherently unstable as they constantly undergo multi-sited transitions, some of which are demonstrated in this paper through an analysis of narratives and practices that seek to impose, restore, or accept multiple versions of normalcy in world politics.

\section{Acknowledgments}

The authors are grateful to Pol Bargues-Pedreny, David Chandler, Jonathan Fisher, Elisa Lopez-Lucia, and Elisa Randazzo for their comments on early drafts of this manuscript. Early versions of this article were presented at the $9^{\text {th }}$ Pan-European Conference of the European International Studies Association in Sicily (2015) and at the International Studies Association's $58^{\text {th }}$ Annual Convention in Baltimore (2017). The authors would also like to thank Matthew Levinger and Laura Roselle for inviting us to contribute to this special issue, Rodrigo Gomes Quintas da Silva for excellent assistance through the production process, and the three anonymous reviewers for providing useful comments. This publication was partially supported by the Journal Publication Scheme of the Faculty of Humanities and Social Sciences at Dublin City University, Ireland.

\section{Conflict of Interests}

The authors declare no conflict of interests.

\section{References}

Anderson, B. (2015). What kind of thing is resilience? Politics, 35(1), 60-66.

Bigo, D. (2008). Security: A field left fallow. In M. Dillon \& A. W. Neal (Eds.), Foucault on politics, security and war (pp. 93-114). Basingstoke: Palgrave Macmillan.

Blanchard, C. (2015, September 8) Saudi Arabia: Background and U.S. relations (Congressional Research Service Report No. 7-5700). Retrieved from: https://fas.org/sgp/crs/mideast/RL33533.pdf

Bonditti, P., Bigo, D., \& Gros, F. (Eds.). (2017). Foucault and the modern international: Silences and legacies for the study of world politics. London: Palgrave.

Bull, H. (1977). The anarchical society: A study of order in world politics. New York, NY: Columbia University Press.

Calhoun, C. (2008). The imperative to reduce suffering: Charity, progress, and emergency in the field of humanitarian action. In M. Bennett \& T. G. Weiss (Eds.), Humanitarianism in question: Politics, power, ethics (pp. 73-97). Ithaca, NY: Cornell University Press.

Caplan, R. (2005). International governance of war-torn territories. Oxford: Oxford University Press.

Caplan, R. (2006). After exit: Successor missions and peace consolidation. Civil Wars, 8(3/4), 253-267.

Caplan, R. (2012). Exit strategies and state building. In R. Caplan (Ed.), Exit strategies and state building (pp. 3-20). Oxford: Oxford University Press.

Center for Strategic and International Studies. (2002). Post-conflict reconstruction: Task framework. Retrieved from: http://csis.org/files/media/csis/pubs/ framework.pdf

Chandler, D. (2014). Resilience: The governance of complexity. London: Routledge.

Donà, M. (2006). Immunity and negation: On possible developments of the theses outlined in Roberto Esposito. Immunitas Diacritics, 36(2), 57-69.

Donais, T. (2012). Peacebuilding and local ownership: Post-conflict consensus-building. London: Routledge.

Duijsens, R., \& Faling, M. (2014). Humanitarian challenges of urbanization in Manila: The position of the Philippine Red Cross in a changing disaster and aid landscape. Resilience, 2(3), 168-182.

Elliott, L. (2003). Reconstituting social order: The United Nations and social reconstruction in disrupted states. In W. Maley, C. Sampford, \& R. Thakur (Eds.), From civil strife to civil society: Civil and military responsibilities in disrupted states (pp. 257-278). Tokyo and New York, NY: United Nations University Press.

Elliott, J. (2005). Using narrative in social research: Qualitative and quantitative approaches. London: Sage.

Esposito, R. (2008). Bíos: Biopolitics and philosophy. Minneapolis, MN: University of Minnesota Press.

European Union Institute for Security Studies. (2013). Ten years after: Lessons from the EUPM in Bosnia and Herzegovina 2002-2012 (Joint Report). Paris: Institute for Security Studies.

Evans, B., \& Reid, J. (2014). Resilient life: The art of living dangerously. Cambridge: Polity.

Finkenbusch, P. (2017). Rethinking neo-institutional statebuilding: The knowledge paradox of international intervention. London: Routledge.

Foucault, M. (1988). Technologies of the self. In L. Martin, H. Gutman, \& P. Hutton (Eds.), Technologies of the self: A seminar with Michel Foucault (pp. 16-49). London: Tavistock.

Foucault, M. (2003). Abnormal: Lectures at the Collège de France 1974-1975 (G. Burchell, Transl.) New York, NY: Picador. 
Grimm, S., Lemay-Hébert, N., \& Nay, O. (2014) Fragile states: Introducing a political concept. Third World Quarterly, 35(2), 197-209.

Guéhenno, J.-M. (2015). The fog of peace: Memoir of international peacekeeping in the 21st century. Washington, DC: Brookings Institution Press.

Hameiri, S., \& Jones, L. (2017). Beyond hybridity to the politics of scale: International intervention and 'local' politics. Development and Change, 48(1), 54-77.

Harris, V., \& Goldsmith, A. (Eds.). (2011). Security, development and nation-building in Timor-Leste: A crosssectoral assessment. London: Routledge.

Herrman, L., \& Vervaeck, B. (2001). Handbook of narrative analysis. Lincoln, NE: University of Nebraska Press.

House of Commons. (2013). The UK's relations with Saudi Arabia and Bahrain (Fifth Report of Session 2013-14). Retrieved from: http://www.publications.parliament. uk/pa/cm201314/cmselect/cmfaff/88/88vw.pdf

Hughes, C., \& Pupavac, V. (2005). Framing post-conflict societies: International pathologisation of Cambodia and the Post-Yugoslav states. Third World Quarterly, 26(6), 873-889.

Ipperciel, D. (1998). The paradox of normalcy in the Frankfurt school. Symposium, 2(2), 37-59.

Jackson, R. (2004) International engagement in war-torn countries. Global Governance, 10(1), 21-36.

Jeng, A. (2012) Peacebuilding in the African Union: Law, philosophy and practice. Cambridge: Cambridge University Press.

Kaldor, M. (1996). A cosmopolitan response to new wars. Peace Review, 8(4), 505-514.

Kappler, S., \& Richmond, O. P. (2011). Peacebuilding and culture in Bosnia and Herzegovina: Resistance or emancipation? Security Dialogue, 42(3), 261-278.

Kratochwil, F. (2010). How (il)liberal is the liberal theory of law? Some critical remarks on slaughter's approach. In L. Morlino \& G. Palombella (Eds.), Rule of law and democracy: Inquiries into internal and external issues (pp. 187-212). Leiden: Koninklijke Brill NV.

Lemay-Hébert, N. (2009). Statebuilding without nationbuilding? Legitimacy, state failure and the limits of the institutionalist approach. Journal of Intervention and Statebuilding, 3(1), 21-45.

Lemay-Hébert, N. (2013). Rethinking Weberian approaches to statebuilding. In D. Chandler \& T. Sisk (Eds.), Routledge handbook of international statebuilding (pp. 3-14). London: Routledge.

Lemay-Hébert, N., \& Kappler, S. (2016). What attachment to peace? Exploring the normative and material dimensions of local ownership in peacebuilding. Review of International Studies, 42(5), 895-914.

Lemay-Hébert, N., \& Mathieu, X. (2014). The OECD's discourse on fragile states: Expertise and the normalisation of knowledge production. Third World Quarterly, 35(2), 232-251.

Mac Ginty, R. (2008). Indigenous peace-making versus the liberal peace. Cooperation and Conflict, 43(2), 139-163.
Mac Ginty, R. (2011). International peacebuilding and local resistance: Hybrid forms of peace. Basingstoke: Palgrave MacMillan.

Martin, L. (2016). Practicing normality: An examination of unrecognizable transitional justice mechanisms in post-conflict Sierra Leone. Journal of Intervention and Statebuilding, 10(3), 400-418.

Miskimmon, A., O'Loughlin, B., \& Roselle, L. (2017). Introduction. In A. Miskimmon, B. O'Loughlin, \& L. Roselle (Eds.), Forging the world: Strategic narratives and international relations (pp. 1-22). Ann Arbor, MI: University of Michigan Press.

Organisation for Economic Co-operation and Development. (2006). DAC statistical reporting directives. Retrieved from: http://www.oecd.org/investment/ stats/31723929.htm

Organisation for Economic Co-operation and Development. (2008). Concepts and dilemmas of state building in fragile situations: From fragility to resilience (OECD-DAC Discussion Paper). Paris: Organisation for Economic Co-operation and Development.

Organisation for Economic Co-operation and Development. (2011). Future global shocks: Improving risk governance. Paris: Organisation for Economic Cooperation and Development.

Randazzo, E. (2017). Beyond liberal peacebuilding: A critical exploration of the local turn. London: Routledge.

Richmond, O. P. (2008). Peace in international relations. London: Routledge.

Richmond, O. P. (2011). A post-liberal peace. Abington: Routledge.

Richmond, O. P. (2013). Failed statebuilding versus peace formation. Cooperation and Conflict, 48(3), 378-400.

Sweetman, D. (2009). Business, conflict resolution and peacebuilding: Contributions from the private sector to address violent conflict. London: Routledge.

Tamer-Chammas, A. (2012). Restoration of damaged land in societies recovering from conflict: The case of Lebanon. In D. Jensen \& S. Lonergan (Eds.), Assessing and restoring natural resources in post-conflict peacebuilding (pp. 203-222). London: Earthscan and Routledge.

Taylor, D. (2009). Normativity and normalization. Foucault Studies, 7, 45-63.

Tisdall, S. (2013, November 11). Typhoon Haiyan: Philippines prepares climate change plans for worse to come. The Guardian. Retrieved from https://www. theguardian.com/world/2013/nov/11/typhoon-haiy an-philippines-climate-change-plans

Tubiana, J., Tanner, V., \& Abdul-Jalil, M. A. (2012). Traditional authorities' peacemaking role in Darfur. Washington, DC: United States Institute of Peace.

United Nations. (2001, April 20). No exit without strategy: Security Council decision-making and the closure or transition of United Nations peacekeeping operations (UN Doc. S/2001/394). New York, NY: United Nations.

United Nations. (2008). Peace operations year in re- 
view 2007. Retrieved from http://www.un.org/en/ peacekeeping/publications/yir/yir2007.pdf

United Nations Development Programme. (2010). Evaluation of UNDP contribution to disaster prevention and recovery. New York, NY: United Nations Development Programme Evaluation Office.

United Nations General Assembly and Security Council. (2005, August 12). Emergency international assistance for peace, normalcy and reconstruction of war-stricken Afghanistan: Report of the SecretaryGeneral (A/60/224-S/2005/525). New York, NY: United Nations.

United Nations Office for the Coordination of Humanitarian Affairs. (2015). An end in sight: Multi-year planning to meet and reduce humanitarian needs in protracted crises (OCHA Policy and Studies Series No. 15). New York, NY: United Nations Office for the Coordination of Humanitarian Affairs. Retrieved from: https://docs.unocha.org/sites/dms/Documents/OCH A_TB15_Multiyear\%20Planning_online.pdf

United Nations Peacebuilding Support Office. (2012). Peace dividends and beyond: Contributions of administrative and social services to peacebuilding. New York, NY: United Nations Peacebuilding Support Office. Retrieved from: http://www.un.org/ en/peacebuilding/pbso/pdf/peace_dividends.pdf

Väyrynen, T. (2010). Gender and peacebuilding. In O. P. Richmond, (Ed.), Palgrave advances in peacebuilding:
Critical development and approaches (pp. 137-153). Basingstoke: Palgrave Macmillan.

Visoka, G. (2016a). Peace figuration after international intervention: Intentions, events and consequences of liberal peacebuilding. London: Routledge.

Visoka, G. (2016b). Peace is what we make of it? Peaceshaping events and 'non-events'. Peacebuilding, 4(1), 54-70.

Visoka, G. (2017a). Shaping peace in Kosovo: The politics of peacebuilding and statehood. Basingstoke; Palgrave Macmillan.

Visoka, G. (2017b). After hybridity? In N. Lemay-Hébert \& R. Freedman (Eds.), Hybridity: Law, culture and development (pp. 301-324). London: Routledge.

Visoka, G., \& Doyle, J. (2014). Peacebuilding and international responsibility. International Peacekeeping, 21(5), 673-692.

Visoka, G., \& Richmond, O. P. (2017). After liberal peace? From failed statebuilding to an emancipatory peace in Kosovo. International Studies Perspectives, 18(1), 110-129.

Wisner, B., Blaikie, P., Cannon, T., \& Davis, I. (2003). At risk: Natural hazards, people's vulnerability and disasters. London: Routledge.

Zanotti, L. (2006). Taming chaos: A Foucauldian view of UN peacekeeping, democracy and normalization. International Peacekeeping, 13(2), 150-167.

\section{About the Authors}

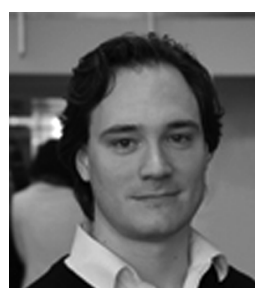

Nicolas Lemay-Hébert is a Senior Lecturer at the International Development Department, University of Birmingham (UK). His research focuses on statebuilding and peacebuilding, local narratives of resistance to international interventions, and the political economy of interventions. He is the co-editor of the Journal of Intervention and Statebuilding and the co-editor of the Routledge Series on Intervention and Statebuilding. His most recent book is The Semantics of Statebuilding (with N. Onuf, V. Rakic and P. Bojanic; Routledge, 2016).

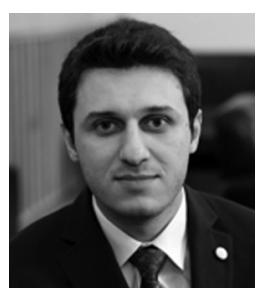

Gëzim Visoka is Assistant Professor of Peace and Conflict Studies at Dublin City University, Ireland. His research focuses on post-conflict peacebuilding, critical theory, and foreign policy analysis. His most recent books include: Peace Figuration After International Intervention (Routledge, 2016) and Shaping Peace in Kosovo: The Politics of Peacebuilding and Statehood (Palgrave Macmillan, 2017). 